\title{
Morpho-sedimentary evidence of Holocene coastal changes near the mouth of the Gironde and on the Medoc Peninsula, SW France
}

\author{
Nigel I. PONTEE, Jean-Pierre TASTET*, Laurent MASSE \\ Département de Géologie et Océanographie, UMR CNRS 5805, Université Bordeaux I, avenue des Facultés, 33405 \\ Talence cedex, France \\ (E-mail tastet@geocean.u-bordeaux.fr)
}

(Revised 26/01/98, accepted 28/01/98)

\begin{abstract}
The Medoc Peninsula is a triangular area of land between the Atlantic Ocean on the west and the Gironde estuary on the east. The Gironde, orientated SF,-NW, is the largest estuary in France. On the Medoc Peninsula Holocene sediments cover a substratum of Tertiary limestones and Plio-Pleistocene fluvial terraces. The Gironde originated as an incised valley during the Weichselian glacio-eustatic fall (100 000-18 000 B.P.) and has acted as a sink for fine sediment throughout the Holocene sea level rise (SLR) (18 000 B.P. onwards). Conversely, the Atlantic littoral zone, characterised by sandy beaches and dunes, has been subjected to erosion throughout the Holocene transgression.

The incised valley of the present Gironde was inundated by the sea approximately 10000 B.P. At this time, the rate of SLR exceeded that of sediment supply, producing a large accommodation space in which transgressive tidal-estuarine muds and sands were deposited. As the rate of SLR decreased around 6000-4000 B.P., sedimentation became more pronounced and the available accommodation space began to decrease significantly. Landward-derived fluvial sediments began to prograde over the tidal muds and sands, and a first generation of salt marshes formed in the lateral valleys. Around 2575-1420 B.P., a sandy chenier ridge formed at the edge of a first generation of salt marshes and wholly or partly separated them from the Gironde. On the eastern side of the ridge a second generation of marshes began to form after 1200 B.P. Reclamation of the first and second generations of marshes occurred during the seventeenth and eighteenth centuries, respectively. On the estuarine side of the eighteenth century dyke the modern intertidal flats and salt marshes began to form after the eighteenth century. Sedimentation within the estuary decreased the accommodation space and led to the increased transport of sediment to the shelf after 2000 B.P. This process was also aided by cliniatic and anthropogenic factors. Future evolution of the Gironde estuary is likely to consist of further marsh growth and chenier development. Howcver, futurc increases in the ratc of SLR, and the degree of storminess, may cause a shift to an erosional regime in parts of the lower estuary.

According to previous work [25,66], three different dune fields migrated landwards across the Atlantic littoral zone over the Holocene period. A field of isolated barchan dunes moved landwards over the Plio-Pleistocene fluvial terraces before 5100 B.P. From some time after this, until around 3000 B.P., a field of parabolic dunes was active. Finally, a barchan dune field was active from around 3000-2000 B.P. to the end of the eighteenth century/beginning of the nineteenth century, when the dunes were stabilised by pine plantations. It is tentatively suggested, using these dates and dune morphology, that dune formation was controlled by sand supply governed by the rate of SLR. However, the role of climatic changes such as aridity, storminess, windiness and the associated effects of vegetation cover, is also likely to be important. In the future the Atlantic coast is likely to continue to erode, although the extensive plantation of the aeolian dunes with pine forests is likely to prevent large-scale transgressive activity. (C) Elsevier, Paris
\end{abstract}

Holocene / coastal change / salt marsh / aeolian dune / chenier

* Correspondence and reprints 
Résumé - Témoins morphosédimentaires des changements côtiers holocènes dans la péninsule du Médoc près đle l'embouchure de l'estuaire de la Gironde. Le Médoc est une péninsule triangulaire séparant l'Océan Atlantique à l'Ouest de l'estuaire de la Gironde à l'Est. Ce dernier, orienté SE-NW, est le plus grand estuaire français. La couverture sédimentaire holocène du Médoc repose sur un substratum de calcaires tertiaires et de terrasses fluviatiles plio-pléistocènes. A l'origine, la Gironde était une vallée incisée formée lors du bas niveau marin correspondant au Weichselien (100 000 18000 B.P.). Cette vallée a joué le rôle de piège à sédiments fins au cours de la remontée du niveau marin depuis le début de l'Holocène (après 18000 B.P.). A l'inverse, la zone littorale atlantique, caractérisée par des plages sableuses et des dunes, a été soumise à l'érosion.

La vallée incisée de la Gironde est pénétrée par les eaux marines vers 10000 B.P. A cette époque, la remontée du niveau marin est plus importante que les apports sédimentaires; des vases et sables estuariens transgressifs s'accumulent dans l'espace d'accomodation ainsi créé. Entre 6000 et 4000 B.P., la remontée du niveau marin s'étant ralentie, la sédimentation devient plus importante, ce qui réduit sensiblement l'espace d'accomodation. Les sédiments terrigènes apportés par le fleuve commencent à prograder sur les vases et sables tidaux et une première génération de marais estuariens se forme dans les vallées latérales. Autour de 2575-1420 B.P., un cordon sableux se met en place sur la bordure externe de ces marais anciens, en les isolant partiellement ou totalement de l'estuaire. Une seconde génération de marais commence alors à se former à l'Est de ce cordon, après 1200 B.P. La poldérisation de ces deux générations de marais a lieu aux XVII et $\mathrm{XVIII}^{\mathrm{e}}$ siècles, respectivement. La sédimentation à l'intérieur de l'estuaire réduit encore l'espace d'accomodation ; les matériaux commencent à être exportés vers la plate-forme, après 2000 B.P. Ce processus est renforcé par des facteurs climatiques et anthropiques. L'évolution future de l'estuaire de la Gironde devrait probablement comprendre de nouvelles phases de croissance des marais et de mise en place d'une ride sableuse coquillière, de type « chenier ». Toutefois, de futurs accroissements du taux de remontée du niveau marin et de la fréquence des tempêtes pourraient provoquer l'apparition de conditions érosives dans certaines parties de l'estuaire aval.

D'après les travaux $[25,66]$, la zone littorale atlantique est caractérisée par l'existence de trois champs dunaires distincts ayant migré vers l'intérieur des terres au cours de l'Holocène : (1) un champ de barkhanes isolées se déplaçant sur les terrasses fluviatiles plio-pléistocènes avant 5100 B.P. ; (2) un champ de dunes paraboliques actives entre 5100 et 3000 B.P. ; el enfin (3), un deuxième champ de barkhanes, mobiles entre 3000/2000 B.P. et la fin du XVIII siècle ou le début du XIX", époque à laquelle les dunes sont stabilisées par des plantations de pins. Sur la base de ces dates et en considérant la morphologie des dunes, il est suggéré que la formation des duncs est contrôléc par la disponibilité du sablc, cllc-même gouvernée par le taux de remontée du niveau marin. Toutefois, le rôle de facteurs climatiques, tels l'aridité, la fréquence des tempêtes, le vent et leurs effets combinés sur la couverture végétale, est probablement important. Dans le futur, la côte atlantique devrait continuer à être soumise à l'érosion que la fixation extensive des dunes éoliennes par la pinède entrave cependant. $O$ Elsevier, Paris

\section{holocène / changement côtier / marais estuarien / dune éolienne / chenier}

\section{INTRODUCTION}

Many low-lying sandy and muddy coastal areas throughout north-west Europe are currently experiencing erosion and marine transgression [77-80]. Increased pressures on the coastal zone due to expanding human development, and predictions of enhanced future rates of sea level rise (SLR) as well as associated increases in storminess, have increased the need for appropriate coastal management. An understanding of large-scale coastal change, involving the physical cvolution of the coastline on a temporal scale of decades or longer, and a spatial scale of the littoral cell [63] is of central importance to coastal management strategies $[12,45,64,95]$. The predictive power of short-term process-orientated studies, which offer insight into the mechanisms of coastal change, is often limited to a scale of tens of years. Simple upscaling of these approaches to cover longer time-scales is often not possible $[55,64,69]$.

One approach to gaining an understanding of large-scale coastal change is to examine sedimentary records, particularly during the Holocene, which can record coastal changes over hundreds to thousands of years. An appreciation of past coastal responses to environmental changes makes it possible to predict the nature and magnitude of future coastal responses. The rapid rates of SLR that occurred during the Holocene may provide an analogue 
for future increased rates of SLR. During the Holocene sea level initially rose at rates of up to $10-15 \mathrm{~mm} \cdot \mathrm{yr}^{-1}$, although this slowed to values similar to those of today after about 6000 B.P. [48, 91]. Analysis of tide gauge records for the last 50-100 years has indicated a rate of SLR of $1-3 \mathrm{~mm} \cdot \mathrm{yr}^{-1}$ [24]. Recent estimates for SLR in the next century range between 3 and $6 \mathrm{~mm} \cdot \mathrm{yr}^{-1}[73]$.

\section{AIMS AND METHODS}

This paper aims to reconstruct as fully as possible the evolution of the Medoc Peninsula (figure l) over the Holocene period. The paper utilises information from a variety of sources: 360 cores held by the BRGM (the French Office of Geological and Mining Research) provided evidence to describe the topography of the preHolocene inundation surface. A further 25 piston cores, up to $10 \mathrm{~m}$ in length, were collected and analysed in detail to describe the history of sedimentation on this surface. Chronological control was provided by the ${ }^{14} \mathrm{C}$ technique, which was used to date peat and shell samples. Coastal dune morphology has also been analysed. Dune fields are important environmental indicators as they result from the interaction of terrestrial, oceanic, atmospheric and biological systems $[49,50,74,78]$. In this study the extent of different dune morphologies was assessed using the 1/25000 topographical maps of the IGN (the French Geolographical Institute), and the geological maps of the BRGM [66]. Reference to aerial photographs was made to examine the morphology of salt marsh creeks. Information from historical records allowed the reconstruction of morpho-sedimentary changes in the study area during the most recent period of the Holocene.

\section{PHYSICAL SETTING}

\subsection{Shelf}

The shelf of the Bay of Biscay is meso- to macro-tidal ( $2 \mathrm{~m}$ range on neaps, $5 \mathrm{~m}$ on springs) and is storm wave-dominated [9, 88]. Bottom tidal currents exceed $0.5 \mathrm{~m} \cdot \mathrm{s}^{-1}$ in the Gironde inlet, but decline rapidly on the inner shelf where values are approximately 0.10 $0.15 \mathrm{~m} \cdot \mathrm{s}^{-1}[60]$. The shelf is exposed to westerly storms and large amplitude/long period swells from the westnorth-west direction. Wave heights reach a maximum of
$9 \mathrm{~m}$ on average 1 day per year. A height of $5 \mathrm{~m}$ is attained during $10 \%$ of the time, and wave periods range between 8 and $15 \mathrm{~s}[60]$.

The sedimentary cover of the Aquitaine shelf has been derived from detrital deposits that have accumulated in the Aquitaine Basin since the Miocene [34, 52, 57]. The shelf sediments consist of shelly gravels to fine-grained sands $[6,9]$. On the inner shelf (8-60 m water depths), part of this sandy substrate consists of fining-up sequences related to storm reworking $[10,93]$. There are two areas of mud deposition located seawards of the two main channels of the Gironde mouth, which form the west Gironde and south Gironde mud patches $[4,61,90]$.

\subsection{The Gironde estuary}

The Gironde has the largest surface area of any estuary in Europe, and is formed by the confluence of the Garonne and Dordogne Rivers [42]. The Gironde estuary has a maximum width of nearly $18 \mathrm{~km}$ near its mouth, tapers to less than $3 \mathrm{~km}$ at the confluence of the two rivers $80 \mathrm{~km}$ upstream, and has a catchment area of $74000 \mathrm{~km}^{2}[2,5]$. The seaward sloping thalweg is incised into a Tertiary carbonate substratum and has a maximal depth, at the mouth of the Gironde, of $45 \mathrm{~m}$ below the present mean sea level (MSL) [5]. The morphology of the Gironde estuary is typical of wave- and tide-dominated estuaries, consisting of: meandering upper estuary channels with tidal-dominated sand and mud estuarine point bars; a mid-estuary funnel-shaped channel containing linear tidal sand bars and estuarine mud; and an estuarine mouth with deeply scoured $(35 \mathrm{~m})$ tidal inlet terminating seaward and landward in sandy shoals $[2,5,16]$.

The discharge of the Gironde varies between 2.5 and $3.5 \times 10^{10} \mathrm{~m}^{3} \cdot \mathrm{yr}^{-1}$. The winter mean flood discharge is approximately $1.4 \times 10^{3} \mathrm{~m}^{3} \cdot \mathrm{s}^{-1}$, and exceptional floods attain $7.5 \times 10 \mathrm{~m}^{3} \cdot \mathrm{s}^{-1}[68]$. The flow rate varies from $200 \mathrm{~m}^{3} \cdot \mathrm{s}^{-1}$ in summer, to more than $5000 \mathrm{~m}^{3} \cdot \mathrm{s}^{-1}$ in periods of spring floods [2]. Tides in the Gironde are semidiurnal with amplitudes ranging from $2.5 \mathrm{~m}$ (neaps) to more than $5 \mathrm{~m}$ (springs) and the tidal currents penetrate further landwards $(100-130 \mathrm{~km})$ than saline conditions $(50-100 \mathrm{~km})$. On the open coast large waves cause a strong littoral drift which introduces large volumes of sand into the estuary mouth $[58,60]$.

At present, the sand carried by the Garonne and Dordogne Rivers accumulates within the Gironde estuary, and none reaches the mouth and adjacent Atlantic coast- 


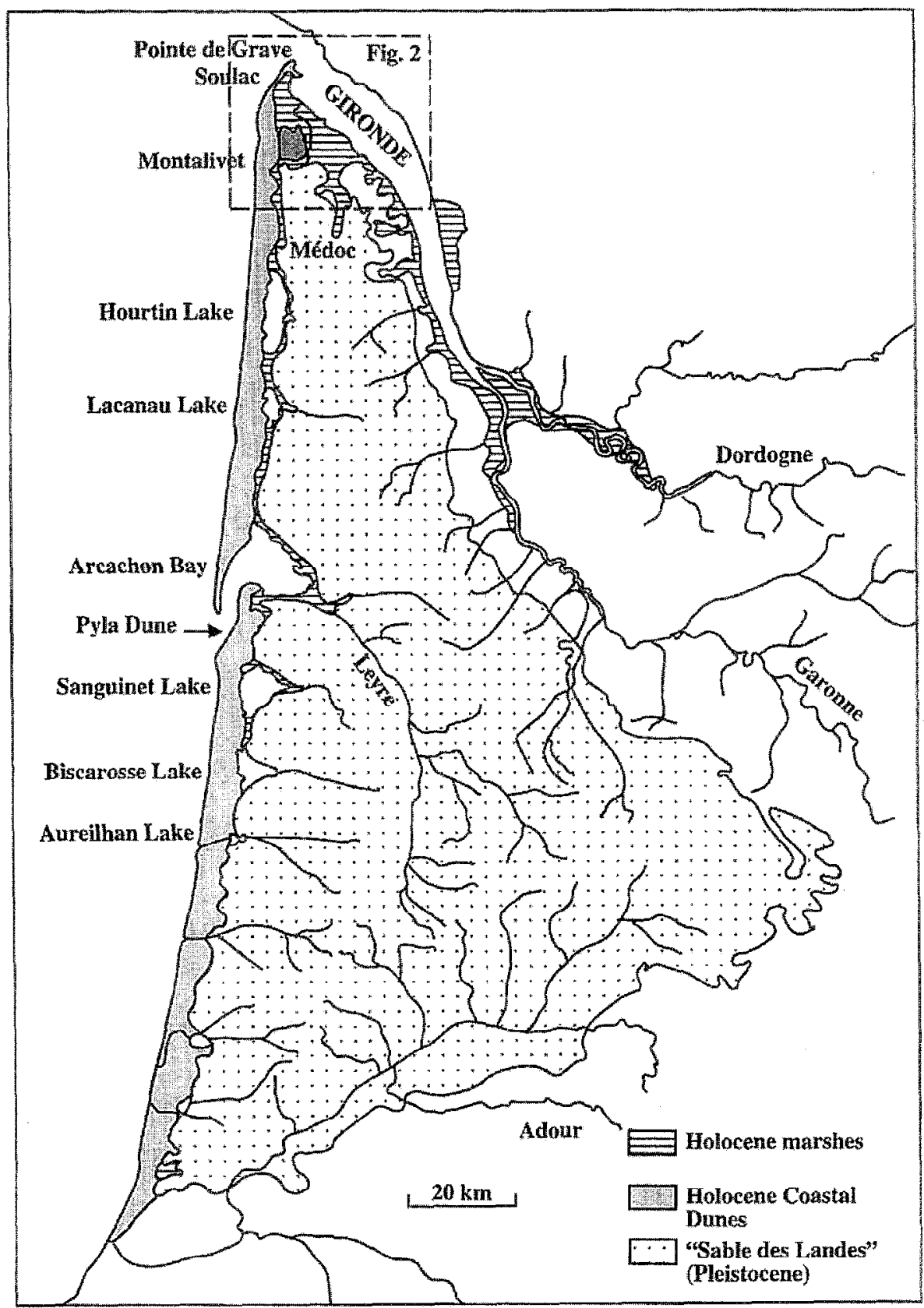

Figure 1. Simplified geological map of the late Quaternary formations in the south-west of France (modified after Enjalbert H., 1973 [27]). The study area is defined by the dashed box.

line $[2,16]$. Approximately $40 \%$ of the fluvially sourced suspended silt and clay is deposited within the estuary. The remaining $60 \%$ of this material reaches the sea, and approximately one third of this is deposited on the shelf mud patches [60]. The suspended sediment yield of the Gironde represents $70 \%$ of the total suspended matter delivered by French rivers to the Atlantic shelf, and $20 \%$ of the total suspended sediment discharge originating from all the great European rivers [19]. The present-day flux of suspended matter is estimated to be between $0.5 \times 10^{6} \mathrm{t} \cdot \mathrm{yr}^{-1}$ during droughts years, and $1.5 \times 10^{6} \mathrm{t} \cdot \mathrm{yr}^{-1}$ in wet periods. Several papers $[43,44,94]$ have shown 
that $90 \%$ of this suspended matter is composed of clay, fine and medium silts.

Studies have shown that the seaward escape of suspended matter from the Gironde estuary is achieved by irregular pulses $[2,3,16,18,32,41]$. The conditions for a maximal escape are: high fluvial discharge, spring tides and floods after long periods of drought [60]. The settling of muds on the middle of the shelf is aided by a vertical thermohaline front within the waters of the shelf during winter time [20].

\subsection{The Aquitaine coast and the Medoc Peninsula}

The Medoc Peninsula is a triangular area of land between the Atlantic Ocean and Aquitaine coast on the wesl, and the Gironde estuary on the east (figure 1). From the mouth of the Gironde in the north to the Adour River in the south, the Aquitaine coast is comprised of a $250-\mathrm{km}$ long, straight and continuous sandy beach [31]. The only major interruption of the beach is the channel of Arcachon Bay, which is partially closed by the Cap Ferret spit. This spit is $25 \mathrm{~km}$ long and has migrated southwards under the influence of a net southerly littoral drift [51]. South of Arcachon Bay there are a number of smaller outlets in the coast and these are locally called 'courants'. Historical records show that the rates of erosion vary along the Atlantic coast, ranging from $1.0-2.0 \mathrm{~m} \cdot \mathrm{yr}^{-1}$ in the northern part of the area $\left(5-10 \mathrm{~m} \cdot \mathrm{yr}^{-1}\right.$ close to the Gironde mouth), to $0.2-1.0 \mathrm{~m} \cdot \mathrm{yr}^{-1}$ in the southern section $[33,51]$.

Along the Aquitaine coast aeolian sand dunes cover an area 0.2 to $10 \mathrm{~km}$ wide, and enclose several large coastal lakes (figure 1). The area of land containing the dunes is known as 'Les Landes de Gascogne', the sandy moor of Gascony, and represents the most important dune system in France [14]. The 'Landes de Gascogne' area is composed of two parts: 1) a coastal dune system and 2) a large inland triangular area, which contains continental dunes and is known as the 'Sable des Landes'. The latter area stretches more than $100 \mathrm{~km}$ inland, and was formed at the end of the last glacial period 20000-10 000 B.P. $[14,33,57]$.

The distribution of the dunes differs along the coast. In the north, crescentic or barchan dunes are dominant, whilst parabolics occur in the centre and increase in importance towards the south [14]. All the dunes formed under a predominant wind direction of $280^{\circ} \mathrm{N}$ [33]. On the Atlantic coast of the Medoc, the BRGM geological map $[25,66]$ shows four generations of aeolian dunes which separate the lakes or marshes from the ocean. These dunes are orientated in a linear fashion along the coast, with the youngest dunes near the present littoral zone and the oldest furthest inland (figure 2). From east to west these dunes are constituted by: 1) isolated barchans, 2) parabolic dunes, 3) localised areas of barchan dunes and 4) present-day littoral dunes. South of the Medoc Peninsula the first generation of barchan dunes is absent, or may be replaced by parabolic dunes, which are evident in some confined areas on the western side of Hourtin Lake (figure 1).

The second generation of barchan dunes form a semicontinuous shore parallel strip from the Gironde to the south of the Aquitaine coast [14], and sometimes coalesce to form large ranges of dunes up to $7 \mathrm{~km}$ wide [11, 33]. Individual dunes may exceed $50 \mathrm{~m}$ in height [11] and are separated by brackish inter-dune depressions locally called 'lettes' or 'ledes' [14]. On the Aquitaine coast parabolic dunes have been reported to be 10-40 m high, 200$1000 \mathrm{~m}$ long, and $\mathrm{V}$ - or U-shaped in plan form. Bressolier et al. [14] and Froidefond and Prud'homme [33] report that the parabolic dunes were covered by pine forests before the seventeenth century. In the Medoc the parabolic dunes reach up to $20 \mathrm{~m}$ in height. On the coast the present-day littoral dunes have been artificially maintained by the French Forestry Service since reprofiling operations in 1827. The forcdunes reach $20 \mathrm{~m}$ in height and extend $300 \mathrm{~m}$ to landward [14]. They are associated with hummocky/chaotic/round dune patterns formed since the ninteenth century, and parabolic dunes occur locally where blowouts ('caoudeyres') develop in areas of sparse vegetation [14].

In the Medoc Peninsula the Holocene sediments cover a substratum of Tertiary limestone and Plio-Pleistocene fluvial terraces (figure 2). The substratum is exposed as hills in the present-day landscape, and these are occupied by the famous vineyards of the Medoc. Between these hills, and westwards to the estuary, lie two generations of Holocene estuarine salt marshes. These marshes are termed the first generation or ancient marshes (locally called 'palus'), and the second generation or recent marshes (locally called 'mattes'). Both marsh formations lie approximately $2 \mathrm{~m}$ above present-day MSL, and are separated by a degraded sandy shelly ridge called 'le Cordon de Richard'. On the eastern side of the second generation of marshes, separated by an eighteenth century dyke, lie the present-day tidal mudflats which show only limited marsh development. Active salt marshes are more 


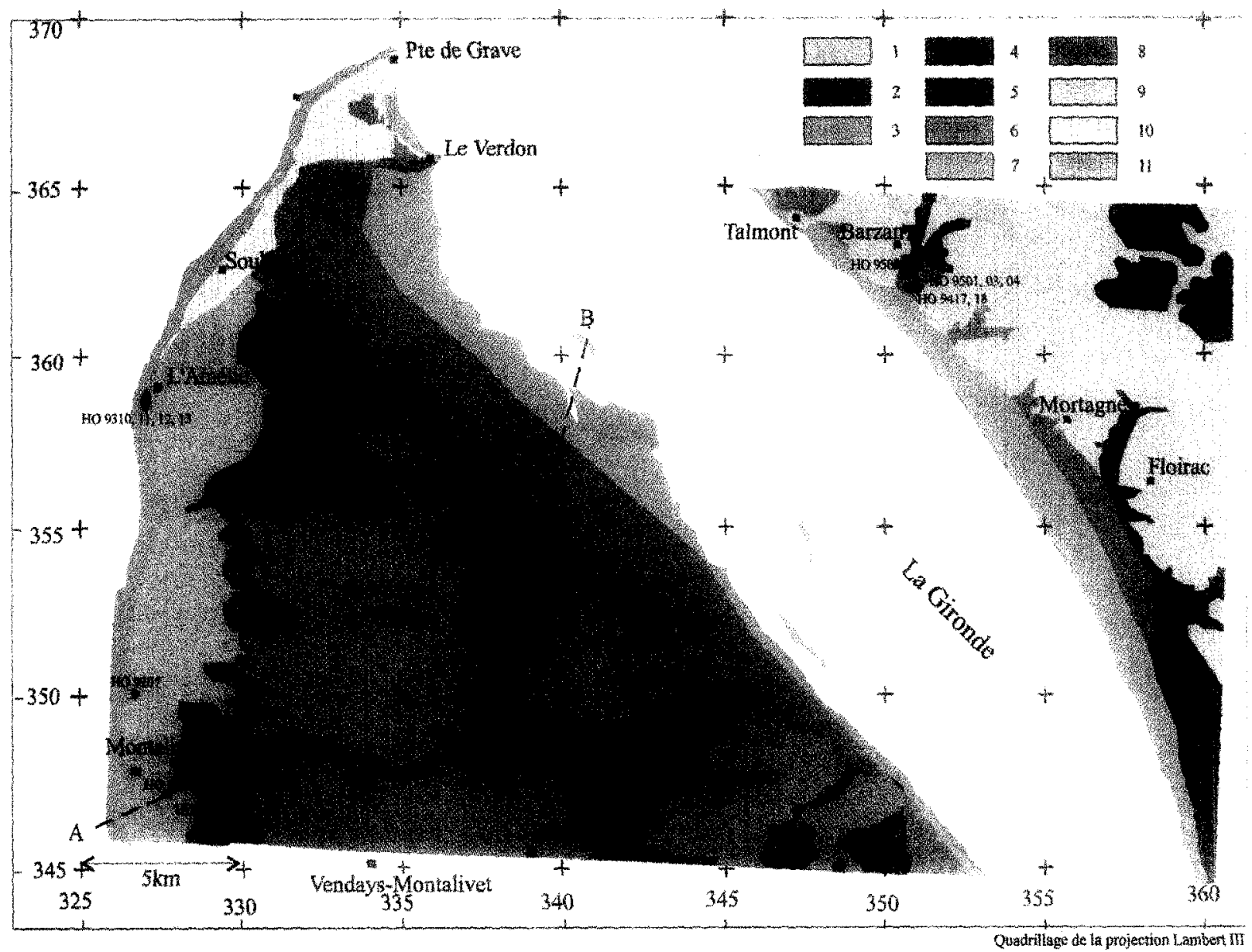

Figure 2. Simplified geological map of the Medoc Peninsula redrawn from the 1/50000 geological map of Saint-Vivien-Soulac [66] and the location of piston cores. 1 = Cretaceous substrate; $2=$ Tertiary substrate; $3=$ Pleistocene fluvial terraces; $4=$ first generation of salt marshes; 5 $=$ Cordon de Richard chenier ridge; $6=$ second generation of salt marshes; 7 = present-day mudflats; $8=$ first generation of dunes (barchans): $9=$ second generation of dunes (parabolics); $10=$ third gencration of dunes (barchans); $11=$ present-day littoral dune (Foredunc).

extensive on the north bank. The two generations of marshes make up most of the present-day Medoc Peninsula, and together with the present-day mudflats form a low gradient coastal plain covering several hundred square kilometres [5].

\section{MORPHO-SEDIMENTARY CHANGES IN THE GIRONDE ESTUARY}

\subsection{History of sea level change}

Previous work has documented the history of SLK all around the world and in northern Europe $[28,29,35,47$, $48,72,82,86]$. Generally speaking, climatic amelioration and eustatic SLR began at about 18000 B.P. Initially MSL rose quickly but slowed down around 60007000 B.P. when MSL approached its present level [28, $47,48,86]$. However, it is difficult to characterise the true nature of MSL variations on a low-lying sandy coasi such as the Aquitaine. In the Gironde area over the last 4000 years, MSL is believed to have fluctuated around the present-day level in a series of positive and negative tendencies, with amplitudes of around $1 \mathrm{~m}$ [81].

\subsection{The formation of an incised valley}

The original incised valley of the Gironde estuary was formed during the last global MSL fall known as the Weichselian glacio-eustatic event, 100 000-18 000 B.P. 
When the maximal eustatic low stand was reached around 18000 B.P., MSL was approximately $100 \mathrm{~m}$ helow its present level. At this time the shoreline was at or near the shelf edge, and the incised valley of the Gironde extended about $135 \mathrm{~km}$ seaward from the present coast. During this period the Gironde deposited sands and gravels $10-30 \mathrm{~m}$ below present MSL, within the thalweg of the incised valley and on the continental shelf $[5,42]$.

\subsection{The flooding of the incised valley by rapid SLR (18 000-10 000 B.P.)}

The incised valley of the Gironde was flooded during the post-glacial SLR, and this gave rise to a ria-type estuary $[83,84]$. At this time the available accommodation space exceeded the fluvial sedimentary flux, and transgressive tidal-estuarine muds and sands began to accrete over the previous low stand fluvial deposits. In the estuarine mouth thick deposits of coarse-grained, estuary mouth tidal inlet and tidal delta sands were deposited over the tidal sediments [5]. These estuarine mouth sands migrated up-estuary throughout the Holocene SLR [5].

In the lateral valleys the Holocene flooding surface is overlain by estuarine clay and sandy sediments reworked from the surrounding fluvial terraces. A compilation of the BRGM coring data for the north Medoc has enabled mapping of the lower limit of this surface (figure $3 a$ ). In some areas, such as beneath the aeolian dunes where there is no core information, a degree of interpretation is required. The flooding surface is characterised by a system of tidal channels which lie between the Tertiary and Pleistocene substratum, are up to $10 \mathrm{~m}$ deep, and converge on the principle estuarine channel. The presence of Holocene freshwater marsh sediments on the beach near L'Amelie also suggests that a channel extended further seawards than the present shoreline.

Around 6000 B.P. (figure $3 b$ ) the volume of the estuary was significantly larger than it is today as tidal flats or marshes had not yet formed. The lateral bays had wide openings onto the estuary, and the estuarine waters reached the hills formed by the gravel terraces. Lesueur et al. [62] reported that oysters and bioclastic debris also extended further inland than at present. At this time the large accommodation space in the estuary meant that all fluvial sediment could be contained within the estuary, and only a very small amount reached the continental shelf.

\subsection{Sedimentation under slow SLR (6000-500 B.P.)}

After the rate of SLR decreased around 6000 B.P., fluvial sedimentation became more pronounced, and began to noticeably decrease the available accommodation space. Mudflats and salt marshes began to develop around the shores of the lateral tidal channels and marginal embayments (figures $3 b, c, d$ ). These deposits smoothed the irregular valley margins, exposed at the end of the Pleistocene, and led to a narrowing of the estuarine channel. At the same time, in the main estuary, landward-derived fluvial sediments began to prograde over the tidal muds and sands. Some authors $[5,60]$ report that in the main estuary the Holocene high stand systems tract forms a seaward-prograding, tide-dominated estuarine bay head delta. These deposits have prograded over the tidal estuarine sands and muds in the upper and middle estuary, and the estuary mouth sand in the lower estuary.

\subsection{The first generation of marshes}

The first generation of marshes lies between the hills of the substrate on the west and the Cordon de Richard on the east (figure 2). The marsh sediments infill former tidal channels which acted as the principle sediment supply routcs to the accreting marshes. In some areas of the Medoc, where agricultural activity has not been too intense, the ancient creek networks can be seen on present-day aerial photographs. Preliminary descriptions of cores taken through these marshes $[23,85]$ show that the Holocene deposits reach up to $10 \mathrm{~m}$ in thickness, and consist of compact clays sparsely interbedded with peat deposits (figure 4). A peat at the head of a palaeo-valley at la Perge, which spans the time of accumulation of the old marshes, enables dates to be given for the formation of the marshes. Near the valley head the peat base was found to be $6053 \pm 72 \mathrm{yr}$ B.P., whilst a sample from near the top of the peat gave a date of $557 \pm 167$ yr B.P. Near the base of the clay closer to the estuary a date of $6700 \pm$ 70 yr B.P. was obtained [23].

Palaeogeographic maps (figures $3 b, c, d$ ) have been constructed to illustrate the general principles of Holocene change in the Medoc area. A number of assumptions were made in the construction of these figures: 1) at 6000 B.P., MSL was placed an arbitrary $2 \mathrm{~m}$ below the present-day level [47]; the steep gradients of the valley margins mean that the choice of sea level does not greatly influence the lateral extent of the marshes; 2) salt marshes occupy the same positions in the tidal 
frame as today, from approximately +3 to $+2 \mathrm{~m} \mathrm{NGF}$ (General Levelling of France); 3) mudflats lie between approximately +2 and -3 NGF. In figure $3 b$ these heights correspond to +1 and $0 \mathrm{~m}$ contours for the salt marshes, and 0 and $-5 \mathrm{~m}$ for the mudflats; 4) the position of coastline was some distance seaward of its present position, although its exact location is unknown.

Figure $3 b$ shows the palaeogeography of the north Medoc around 6000 B.P. The marshes can be seen to occupy the heads of the tidal channels. At the start of their formation the first generation of marshes would have been salt marshes. However, during their later stages it is likely that they became increasingly brackish, and perhaps even fresh water in their landward extremities (see [23]).

\subsection{The sandy ridge 'Cordon de Richard'}

The Cordon de Richard is a ridgelike feature composed of sand, pebbles and shells. It separates the two generations of marshes, or lies against the Plio-Pleistocene flu-

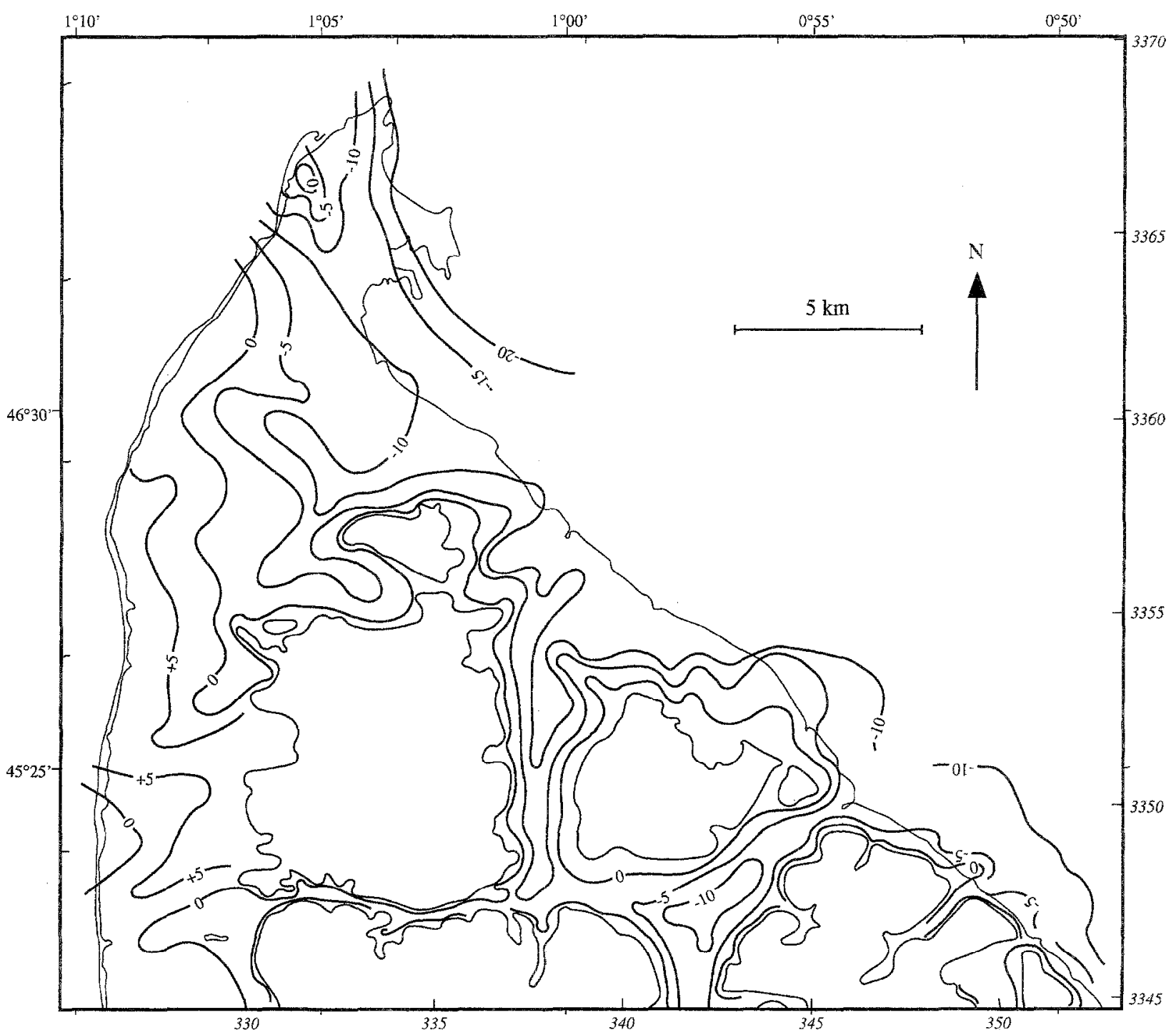

(a)

Figure 3. (a) Isobath map of the base of the marsh clays and dune sands which represent the Holocene inundation surface around 6000 B.P. 
(b)

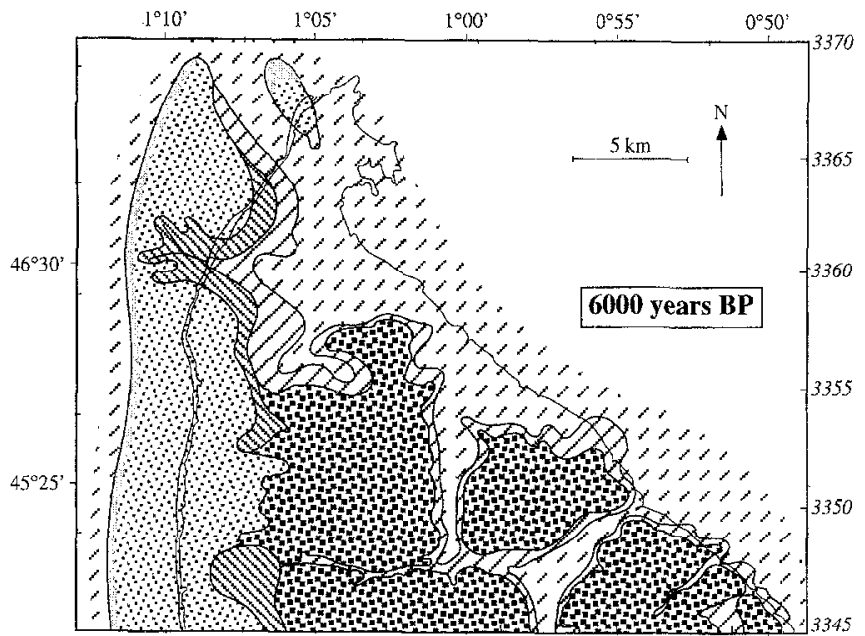

(c)

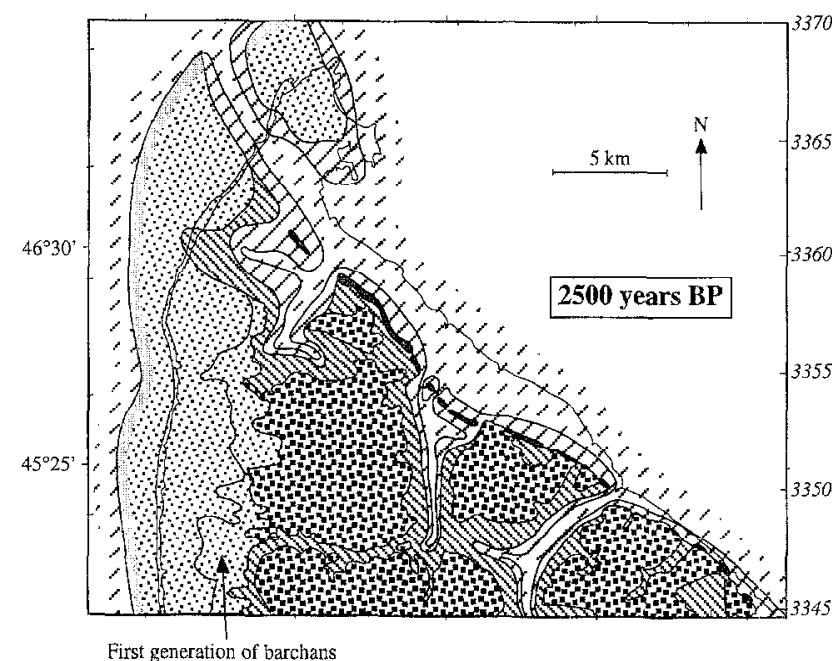

\section{$\because$ Subtidal zone \\ [Z] Mud flats}

Cordon de Richard (chenier ridge) $\$$ First generation of marshes 20 Second generation of marshes Littoral foredune Seolian dunes

FIP Pleistocene fluvial terraces

(d)

Figure 3 (cont.). (b, $c$ and d): Paleography of the north Medoc through the Holocene period. (b) c. 6000 B.F. (4000 B.C.) the fine line is the actual coastline. (c) c. 2500 B.P. (500 B.C.) 1 - dunes parabolic, 2 - shelly sartuly ridge of 'Cordon de Richard'. (d) c. 1500 B.P. (500 A.D. - the Middle Ages) 3- barchan dunes.

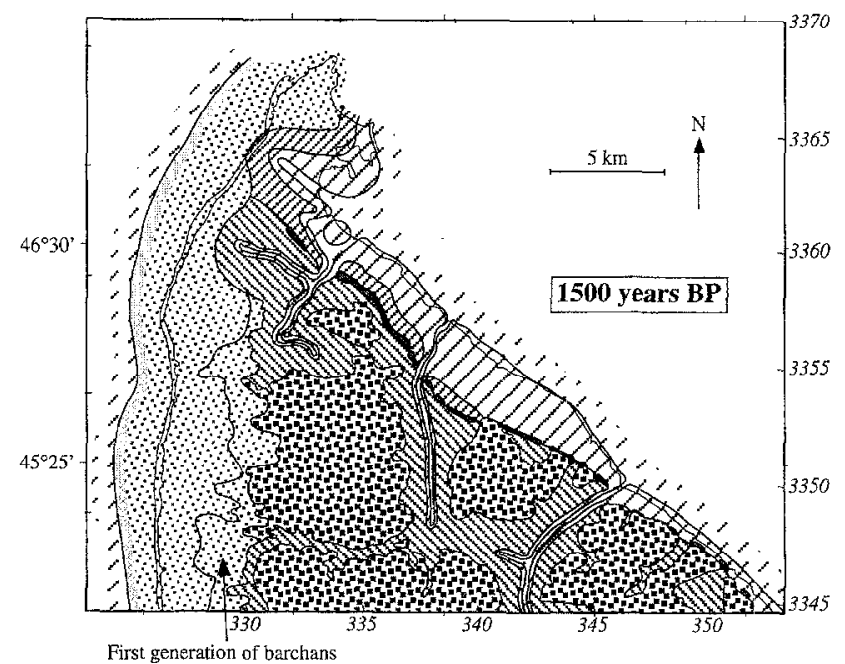




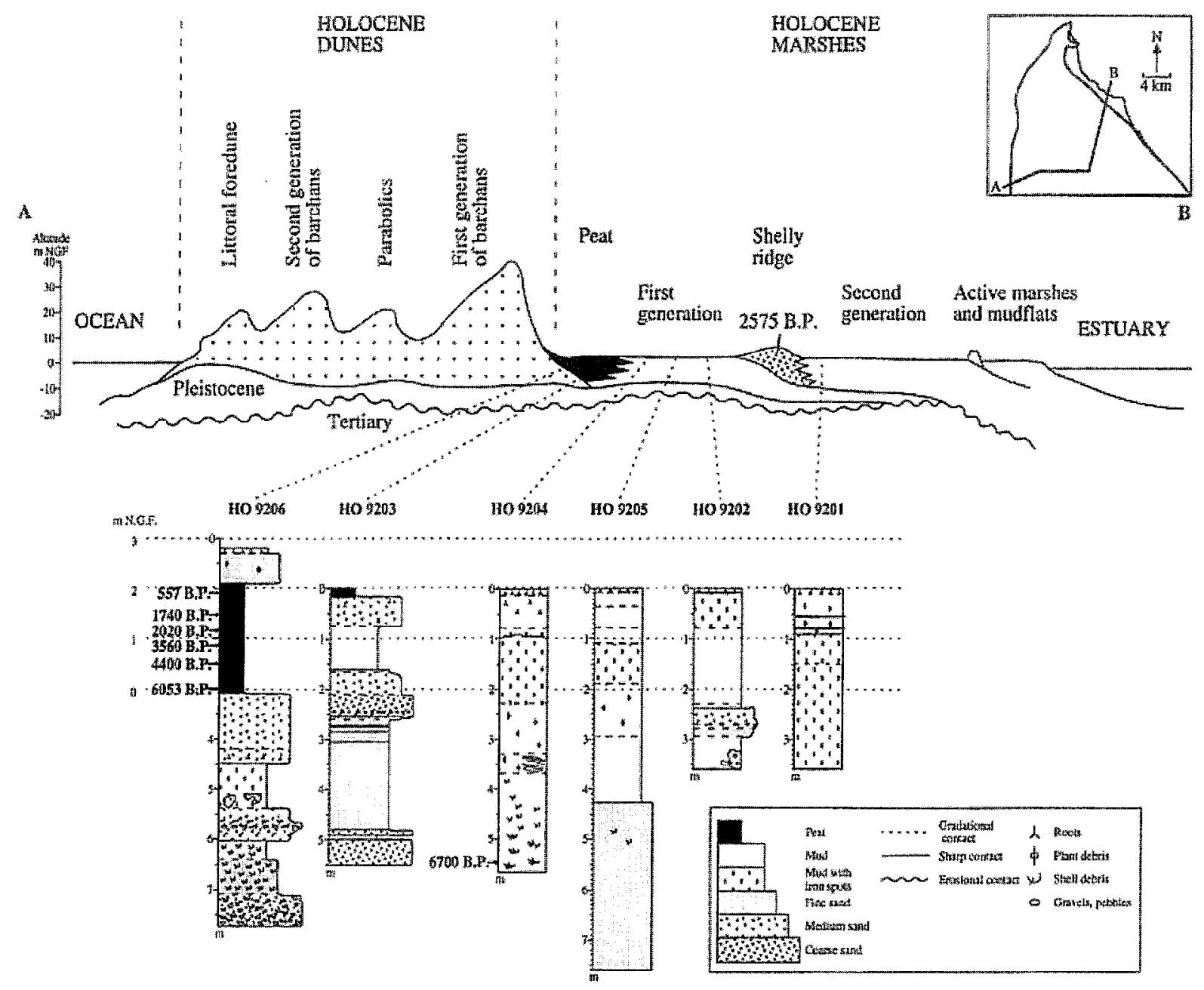

Figure 4. Schematic geological west-east cross section through the Medoc Peninsula (location of piston cores in figure 2).

vial terraces to the west. A Scrobicularia shell, taken from the main body of the Cordon de Richard, near the village of Balluards, has been dated at $2575 \pm 120 \mathrm{yr}$ B.P. Another date obtained $3 \mathrm{~km}$ south-east of this sample, from a recurved spit of the ridge near to an inlet adjacent to the village of Les Cabireaux, gave a date of $1421 \pm$ $162 \mathrm{yr}$ B.P. The internal sedimentary structure of the ridge was observed in a drainage pit located between Port de Richard and Les Avents, and consisted of beds that dip gently towards the estuary. Due to its morphology and structure, the Cordon de Richard is interpreteted as a chenier ridge.

Figure $3 c$ shows the palaeogeography of the north Medoc around 2500 B.P. The extent of the marshes was esti- mated by assuming that the mature marshes occupied the whole of the area above the $-5 \mathrm{~m}$ contour. The position of the tidal channels was taken to lie between the sections of the Cordon de Richard as shown on the BRGM geological map $[25,66]$. The mudflats were assumed to exist on the estuarine side of the Cordon de Richard below the $-5 \mathrm{~m}$ contour, and estimated to have a width of approximately $1 \mathrm{~km}$.

By the time of ridge formation under wave action, continued fluvial supply of sediment into the estuary had led to increased sedimentation in the inter-tidal areas. This process raised the levels of mudflats within the tidal frame, and allowed marsh vegetation to colonise a larger area. The marshes, therefore, expanded outwards from their 
previous locations along the edge of tidal channels. As well as increasing their lateral extent, the marshes also accreted vertically within the tidal frame $[6,71]$. This increase in the marsh volume led to a decrease in the palaeobathymetry of the estuary, and a subsequent reduction of the disequilibrium between accommodation space and sediment supply. Observations from the shelf adjacent to the mouth of the Gironde estuary show that mud deposition began around 2000 B.P. [60], illustrating that fluvial sediment began to reach the continental shelf at this time.

\subsection{The second generation of marshes}

The second generation of marshes extends from the Cordon de Richard on the west to the present-day sea embankment on the east. A Scrobicularia shell taken from these marshes gave a date of $1199 \pm 136 \mathrm{yr}$ B.P. Figure $3 d$ shows the palaeogeography of the north Medoc around 1450 B.P. (500 AD - the Middle Ages). The extent of the marshes was estimated after assuming they had started to form in front of the Cordon de Richard.

The continued supply of fine-grained material to the estuary allowed the further progradation of the marshes, which resulted in a further decrease in the size and landward penetration of the tidal channels. From the Middle Ages (1000-500 B.P.) onwards, increasing amounts of sediment began to reach the Aquitaine shelf. This was coincident with the estuary reaching an equilibrium stage marked by the development of its present-day funnel shape. The more rapid supply of sediment to the shelf led to increased sedimentation rates in the Gironde mud patches from the Middle Ages onwards. Lesueur and Tastet [60] reported that this increasing sediment supply was aided by increased sediment concentrations within the Gironde, which may also have increased deposition rates on the marshes and mudflats. These authors [60] cite a number of reasons for these increased concentrations: 1) modifications to the mouth of the estuary, such as the opening of the southern channel ('Passe Sud') in the main estuary between 1500 and 1000 B.P. (450-950 A.D.) [1]; 2) periods of major deforestation [62] which occurred: i) during the Roman occupation [65], ii) from the end of eleventh century (900 B.P.) to the thirteenth century (700 B.P.) and iii) during the sixteenth and seventeenth centuries (400-300 B.P.); and 3) periods of significant climatic cooling, with an associated increase of annual precipitation: i) before $1000 \mathrm{AD}$ (950 B.P.) $[13,53,59]$ and ii) hetween the sixteenth and nineteenth centuries (400-100 B.P.; (the 'Little Ice Age') $[39,54,59,96]$.

\subsection{Recent evolution under slow SLR (seventeenth to twenty-first century)}

The first generation of marshes were drained and reclaimed (polderised) around the seventeenth century (300 B.P.). This involved the strengthening of the Cordon de Richard in some places [1], and the artificial extension of the northern limit of the ridge by the construction of a dyke (locally known as the 'Dutch dyke'). The second generation of marshes were polderised in the eighteenth century (200 B.P.) by the construction of an earth embankment on their estuarine side. The presentday tidal flats began to accumulate on the estuarine side of this embankment following its construction. Since reclamation both generations of marshes have been subject to grazing, and for the last 20 years, intensive agriculture.

Historical records from Roman times and bathymetric charts dating back to the seventeenth century (300 B.P.) indicate a gradual filling of the estuary with fluvial $[2,18$, $60,67]$. During the second half of the eighteenth century major morphological changes occurred within the Gironde. At the mouth of the estuary these changes included the opening of the western channel ('Passe Ouest') across the sand banks, the deepening of the southern channel ('Passe Sud') and increasing erosion of the Atlantic coast of the Medoc [40, 61]. From 1770-1780, the principle estuarine channel migrated towards the north and attained its maximal width in approximately 1910 [2]. Bathymetric evidence from the eighteenth century (200 B.P.) suggests that today the Gironde has reached a state of equilibrium $[17,67]$ and appears to be a relatively mature estuary [18].

Lesueur and Tastet [60] reported that since 1850 channel management has been carried out progressively further seaward, culminating in the opening of the present manmade Great Western channel in 1930. After 1939, and particularly during the 1960 s, there was intensive dredging [68]. Lesueur and Tastet [60] reported that dredging and channelisation have led to increases in: 1) the concentration of the fine-grained sediments in the lower estuary, 2) sedimentation in stagnant areas such as marginal bays and abandoned channels and 3 ) the expulsion of suspended matter to the shelf $[18,30]$. 


\section{MORPHO-SEDIMENTARY CHANGES ON THE ATLANTIC SIDE OF THE MEDOC PENINSULA (AEOLIAN DUNE DEVELOPMENT)}

According to the geological maps of the BRGM $[25,66]$, the oceanic side of the Medoc Peninsula has suffered three dune invasions (figure 2). The oldest dunes located furthest inland are represented by a field of isolated barchans which reach the head of the valleys occupied by the first generation of Medoc marshes. According to the dates provided by Marionnaud [66] and Dubreuilh and Marionnaud [25], these dunes were active before 5100 B.P. At this time the coast would have been substantially westward of its present location due to the long history of erosion throughout the Holocene transgression. Figure $3 a$ shows that near the mouth of the Gironde around 6000 B.P., there was an indication of high land in the vicinity of the Pointe de Grave. Allowing for the subsequent erosion of the seaward side of this feature, it seems likely that there could have been a sandy island capping the St. Nicolas rocks (figure $3 b$ ) around 6000 B.P. $[83,84]$.

According to dates given by the BRGM, in the north Medoc the parabolic dunes that overlap the first generation of barchans were active from 5100 to 3000 B.P. The same authors indicate that the third generation of dunes, represented by barchan dunes that locally overlap the parabolic types, were active from 3000 B.P. to the nineteenth century, when they were stabilised by forest plantations between 1787 and 1864. On the Aquitaine coast, Barrere [11] reported that the second generation of barchan dunes were mobile in the Middle Ages, and that dune transgression occurred after the forest was established. This author [11] reported that inland sand movement was manifest as long tongues of sand, small dunes transverse to the coastline and low parabolic dunes. Froidefond and Prud'homme [33] believed that the round or chaotic dunes, located in between the second generation of barchans and the foredune area, developed recently in the presence of vegetation.

To the south of the Medoc Peninsula the first generation of barchans are absent. In the Dune du Pyla area Froidefond and Prud'homme [33] believed that these barchanoid dunes were reworked into parabolic forms from 3000 to 1000 B.P. To the south of the Medoc Peninsula a close inspection of the BRGM map [26, 46] shows that the barchan dunes, which form the second generation of dunes in the north Medoc, may be divided into three types:
1) massive barchans, responsible for lake formation, mobile from 3000 B.P. to the thirteenth century. These dunes are generally $30-45 \mathrm{~m}$ high but reach $45-60 \mathrm{~m}$ south of Archachon Bay.

2) small reworked parabolic dunes, mobile between the thirteenth and the seventeenth centuries. These dunes are very difficult to distinguish with only a few examples identifiable on the topographical map.

3) transverse dunes with barchanoid crests, transgressing the previous dunes and mobile between the seventeenth and nineteenth centuries. These dunes are less than $30 \mathrm{~m}$ high but reach 50-60 m south of Archachon Bay.

In the Dune du Pyla area (figure 1) Bressolier et al. [14] interpreted three phases of dune activity on the basis of dated palaeosols. The first of these dune-building episodes was believed to have occurred from 3000 to 1000 B.P., and to have resulted in parabolic dunes, which contributed to the partial or complete closure of small estuary mouths leading to the formation of lagoons. The second phase of dune activity occurred from 2400 to 500 B.P. (and also later), and was thought to have resulted in barchan dunes, which completed the enclosure of the Landes lagoons, leaving only two harrier lagoons (Aureilhan and Leon) connected to the sea [14] by the 'courants'. According to the same authors, man settled in the sparse pine/hazel forest towards 2000 B.P., and around 1500 B.P. coastal barchan dunes moved inland, invading the parabolic dune system and burying vegetation. The third and final phase of dune activity in the Dune du Pyla area is believed to have occurred since the end of the nineteenth century.

\section{DISCUSSION - MORPHOLOGICAL EVOLUTION, MSL AND CLIMATE CHANGE}

\subsection{The Gironde estuary}

The limited number of dated samples in the two generations of marshes, and the lack of detailed information about the stratigraphic relationship between these marshes and the Cordon de Richard, prevent a full understanding of the detailed evolution within the Gironde estuary. However, some insight as to the likely course of events may be gained by a review of similar environments found elsewhere in the world.

Ridge features similar in size and composition to the Cordon de Richard have been described by a number of 
authors $[37,56]$. From these works it appears that the Cordon de Richard represents a chenier-type ridge formed high on an inter-tidal mudflat or at the seaward edge of a salt marsh. Chenier formation has been noted to be primarily dependant on the onshore supply of material from inter-tidal [56] as well as sub-tidal areas [37]. In the case of the Cordon de Richard, it is possible that some material was also incorporated into the ridge by longshore transport from the Plio-Pleistocene gravel terraces. Sediment supply to a chenier is often governed by hydrodynamic conditions. Causal factors include pulsatory sediment supply from rivers [36; cited in 56], increased rates of SLR [87; cited in 56,38], and increased storm activity $[38,56]$. In marshes in Essex, United Kingdom, Greensmith and Tucker [38] considered that chenier inigration was favoured by periods of marsh erosion associated with increased rates of SLR which acted to supply material to the ridges by the crosion of previous coarse sediments. However, in Korea, Lee et al. [56] reported that a chenier had accumulated since 1800 B.P. independently of sea level, and was caused entirely by wave action leading to the coalescence of inter-tidal sand shoals. In the case of the Gironde estuary the formation of the Cordon de Richard could be due to external or internal factors. External factors may include an increase in the SLR and/or an increase in storminess. Internal factors include changes in the estuarine mouth such as the opening of the southern channel in 1500-1000 A.D. [62], which may have led to an increased marine influence within the estuary. In addition, a shift in the position of the main estuarine channel could have prompted a change in sediment supply, wave energy and the onset of erosive conditions [7].

Once formed, the Cordon de Richard would have partially enclosed the first generation of marshes. It is likely that the ridge blocked some of the smaller creeks draining the marshes isolating the marshes behind from a direct tidal influence. Greensmith and Tucker [37] noted how chenier ridge formation created embayments which then underwent progressive siltation up to marsh level. From the segmented nature of the Cordon de Richard (figure 2), it appears that the strong tidal currents flowing in larger creeks draining the first generation of marshes prevented ridge formation, and in some locations gave rise to spitlike features. This is comparable with observations made by Greensmith and Tucker [37]. These large channels would have allowed the contemporaneous accretion of the first and second generation of marshes.

\subsection{Aeolian dunes}

Coastal dune formation can be thought of as needing three major requirements: 1) sand supply, 2) a strong onshore wind for at least part of the year and 3) an area in which sand can accumulate [21]. Pye [75, 76] considered that the form and scale of aeolian sand accumulations was likely to be determined by seven main factors: 1) sand availability, 2) grain-size distribution, 3) wind velocity distribution and directional variability, 4) vegetation cover and growth characteristics, 5) the nature of the surrounding and underlying topography, 6) climatic and sea level changes and 7) long-term patterns of tectonic uplift and subsidence.

Four alternative models of formation have been proposed that relate to coastal dune formation and the position of MSL ([78], see figure 5). These are: 1) dune formation under interglacial high sea level; dune stabilisation under glacial low sea level; 2) dune formation under glacial low sea level, when there is a large sand supply resulting from the exposure of continental shelf deposits coupled with sub-aerial weathering and fluvial supply, in drier and windier conditions; 3) dune formation as a mechanism of shore progradation during regressions; dune stabilisation under rising sea level when there is a reduction in the landward transport of sand, cessation of shorelinc progradation and a reduction in the supply of aeolian sand; and 4) dune building during transgressions when rising sea level causes destruction of foredune and beach ridge vegetation, blowout formation and the initiation of transgressive dunes; dune stabilisation during regressions.

There is evidence from different parts of the world for all of these hypotheses of dune formation. Dune formation during regressive phases has been documented in the United Kingdom [15, 79] and in California [70]. Conversely, in south-east Australia, Pye [78] found that transgressive dunes were active under rising sea level, but became stabilised (being subject to pedogenesis and weathering) under stable or low sea level. Such variability in dune formation with respect to sea level may perhaps be expected due to the number of factors governing dune formation. This is supported by the findings of a number of authors. For example, in Denmark, Christiansen et al. [21] reported that under present-day conditions transgressive dune activity was not occurring, despite rising sea level and coastal erosion, since the dunes had been successfully stabilised with vegetation and there was limited sediment supply. In the Netherlands, the Older Dunes and Younger Dunes were both 


\section{A HIGH SEA LEVEL MODEL}

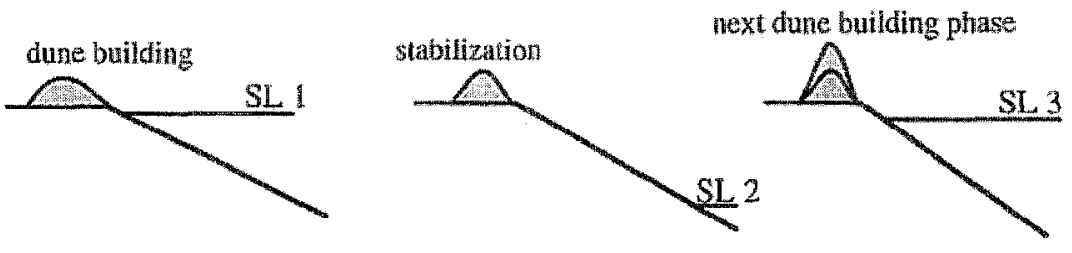

B LOW SEA LEVEL
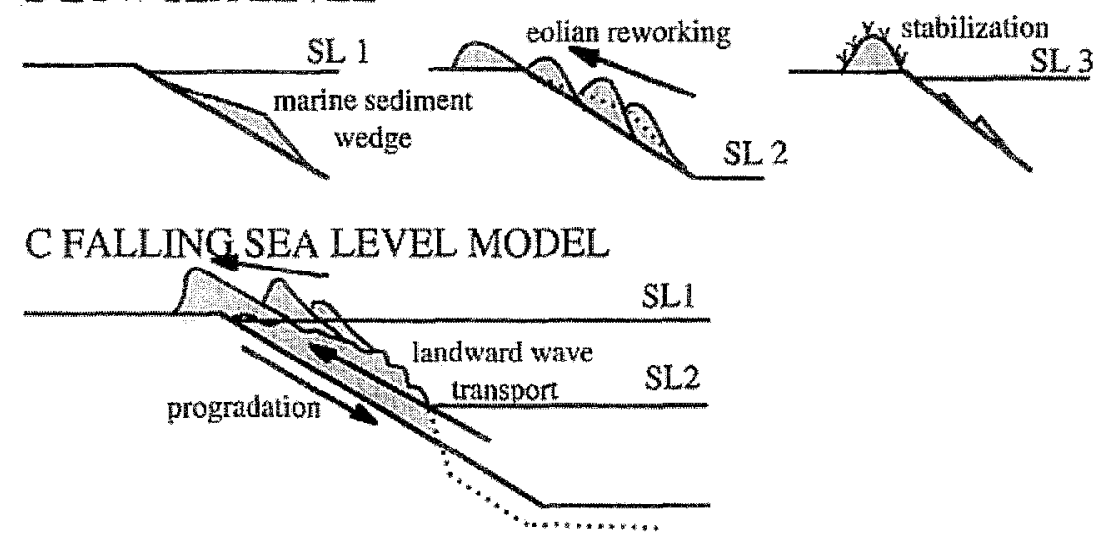

D RISING SEA LEVEL MODEL

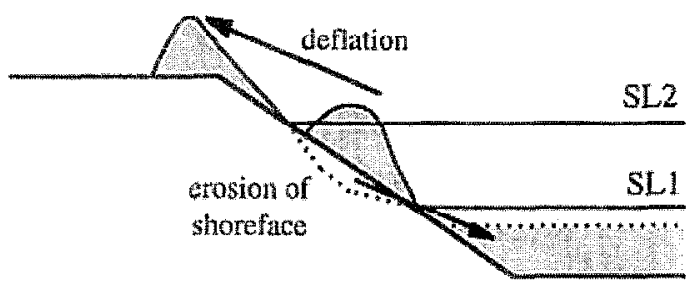

Figure 5. Four models illustrating the evolution of coastal dunes with respect to sea level variations (from Pye, 1984 [74]).

formed under rising sea level. However, for the Older Dunes this was associated with coastal progradation, whilst for the Younger Dunes it was associated with coastal erosion $[49,97]$. Even where coastal erosion is instrumental in dunc formation, such as in south-cast Australia, it may result from a number of causes [78]. Such causes can include increases in storminess or a reduction in near-shore sediment supply as well as increased rates of SLR [78]. Dune activity may also be increased by vegetation disturbance resulting from periods of disease, changing soil nutrient status or vegetation life-cycle variations or anthropogenic activity [78].

On the Aquitaine coast of France previous work has favoured dune formation under falling sea level conditions which through coastal exposure supplied sand to the dunes, whilst positive sea level tendencies favoured the erosion of the coast and the fixation of the dunes by a more humid climate and a rise in ground water levels. The evolution of the Medoc Peninsula could be interpreted as being formed under a series of positive and negative sca level tendencics that affected the area after 6000 B.P. (table I) $[83,84]$. In the Dune du Pyla area, Bressolier et al. [14] also believed that dunes were active during regressive periods, but also considered climatic change to be important.

The following discussion is based solely on the dates given by the BRGM map of Marionnaud [66] and Dubreuilh and Marionnaud [25]. The discussion is limited by the lack of a detailed chronology of dune development and the absence of an accurate sea level history for the region, which prevent comparison with well-docu mented dune chronologies such as those in The Nether- 
Table I. Tastet's [83, 84] interpretation of the evolution of the north Medoc Peninsula under positive and negative sea level tendencies.

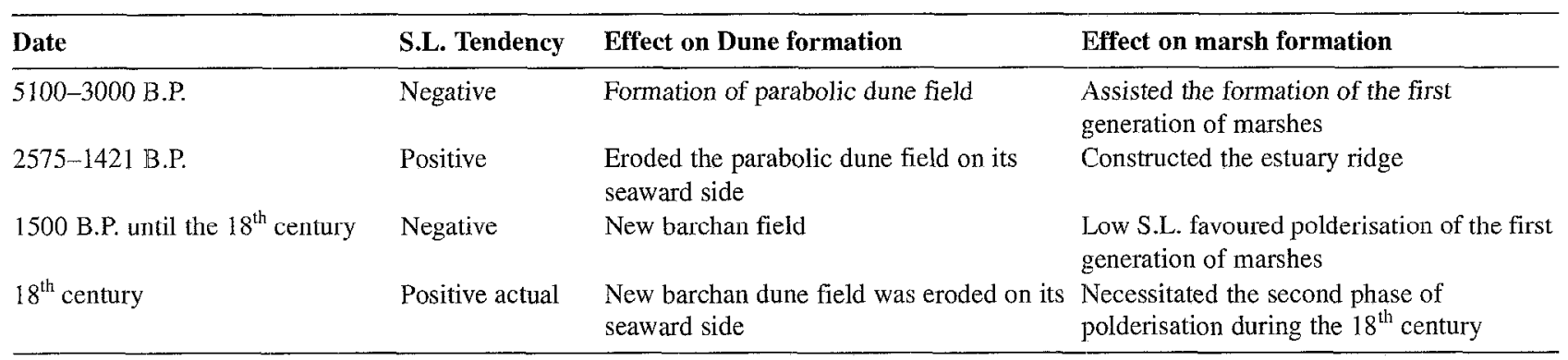

lands $[50,97]$. However, a review of factors controlling dune formation enables some useful insights into Holocene dune development on the Aquitaine coast.

Barchans are usually taken to indicate high sand supply [70] in highly arid areas with unidirectional wind [75, 76]. Thus, the first generation of barchans thought to be active before 5100 B.P. $[25,66]$ could be taken to indicate either a high sand supply arising from coastal erosion due to rising sea level or high storminess, or high sand transport arising from an arid climate, strong winds and lack of vegetation. In the Medoc area it is believed that SLR could have been the most important factor since the period of barchan formation corresponds with a period of rapid SLR., whilst the cessation of barchan activity corresponds with the stabilisation of SL around 6000 B.P.

In the largest sand islands in the world (south-east Australia), large-scale parabolic dunes formed in response to rapidly rising sea level $[74,76]$ and massive sand supply from the transgressed shelf. However, in the coastal setting parabolics have been reported to form as sea level stabilises and sand supplies decrease [70]. Likewise, a vegetated substrate favours parabolic dune formation by inhibition of sand transport. Thus, in the Medoc, the formation of parabolic dunes from 5100 to 3000 B.P. [25, 66] seems to be in agreement with the interpretation of Orme [70] and could be taken to indicate either a decrease in sand supply due to a cessation of coastal erosion caused by at stabilisation of sea level, possibly coupled with a decrease in storminess, or a decrease in sand transport due to the development of vegetation associated with a change to a more humid climate. In the Medoc area it is believed that the present sea level was reached around 6000 B.P., and this could therefore explain the decrease in aeolian sand supply. However, the role of climate and vegetation cannot be ruled out.

The second barchan dunes, active from 3000 B.P. to the nineteenth century (100 B.P.) $[25,66]$, could indicate: 1 ) an increased sand supply due to increased coastal erosion resulting from an increased rate of SLR and/or increase in storminess or 2) increase in sand transport due to a drier climate/increase in windiness/decrease in vegetation cover. In the Medoc, during the period 3000-100 B.P., a number of environmental changes occurred which could have led to increased sand supply and transport. These were: 1) a sea level fall $2400-1500$ B.P. interpreted to have occurred by Bressolier et al. [14];2) an increase in storminess and in the rate of SLR around 1500 B.P. [14], or around 1850 B.P. as possibly suggested by the formation of the Cordon de Richard ridge in the estuary; 3) several increases in windiness interpreted by Bressolier et al. [14], to have occurred during the periods of 24001500 B.P., around 600 and 1300 A.D. (1300 and 650 B.P.), during the Middle Ages and during the seventeenth and eighteenth centuries (300-100 B.P.); and 4) climatic changes - the Medieval warm period $900-1000$ B.P. [22, 54], followed by a cool period $1550-1150$ B.P. [13, 53, $59,60]$.

\section{CONCLUSIONS}

The following summary represents the best attempt to reconstruct the Holocene changes in the Medoc area with the data currently available.

- From 18-10000 B.P. SLR was rapid and led to the flooding of the incised valley of the Gironde and the formation of a ria. In this ria the accommodation space was much greater than the fluvial sediment supply, and marine sediments prograded landward. On the Atlantic coast rapid coastal erosion provided a large supply of sand for aeolian activity, and led to the formation of the first generation of barchan dunes from approximately 10000 to 5100 B.P. $[25,66]$. 
- In 6000 B.P. the rate of SLR slowed (possibly accompanied by a decrease in storminess). In the Gironde, salt marshes began to accumulate in the lateral valleys, and fluvial sediments prograded seawards in the main channel. On the Atlantic coast erosion rates decreased, leading to a decrease in the sand supply for aeolian activity. This caused the formation of barchan dunes to be arrested and the subsequent formation of a new generation of parabolic forms from 5100 to 3000 B.P. [25, 66].

- A SLR and an increase in storminess possibly led to the formation of a shelly ridge in the estuary around 2000 B.P. (2575-1421 B.P.). Around this time mud began to reach the continental shelf [62] due to decreased accommodation space within the estuary. The formation of the second generation of marshes from 1200 B.P. to the eighteenth century (200 B.P.) represented a period of accretion under steady SLR. The growth of these marshes [89] and the increasing sedimentation rate in the Gironde shelf mud patches from the Middle Ages onwards [60], were all aided by high fluvial suspended sediment concentrations within the Gironde. These conditions resulted from several periods of deforestation, and two periods of cooler climatic conditions [5]. Additionally, changes in configuration at the estuary mouth coupled with an increase in channel management were also important in increasing the supply of material to the shelf. On the Atlantic coast the formation of the second generation of barchan dunes occurred from around 2000 B.P. to the eighteenth century $[25,66]$, when they were artificially vegetated. These barchans possibly indicate one or more of the following: an increase in SLR, an increase in storminess, an increase in windiness or a decrease in vegetation cover.

Throughout the Holocene SLR and post-Holocene high/ still stand, the Gironde has acted as a long-term sediment sink leading to a marked reduction in capacity [5]. Today, the estuary continues to evolve as it has since 6000 B.P. On the estuarine side of the eighteenth century embankment there is a sandy/shelly beach which in places forms a series of ridges. These ridges are considered to provide a good analogy to the Cordon de Richard. Additionally, a satellite 'Spot' image shows the accumulation of coarse sediments in the middle of the mudflat in Verdon Bay, which may represent a precursor for ridge formation. Further ridge development may lead to the isolation of an area of mudflat that may then become colonised by marsh vegetation [83, 84]. Since the Gironde estuary has reached a state of equilibrium, it is possible that in the longer term (hundreds to thousands of years) increased SLR may cause an erosion of the mudflats and marshes in the lower estuary. This process has been observed in the Severn estuary in south-west England by Allen [8].

In contrast to the infilling of the Gironde, the Atlantic littoral zone of the Medoc, characterised by sandy beaches and dunes, has been subjected to erosion throughout the Holocene SLR. This has been due to a high wave energy input, and strong longshore and offshore transport, which has led to the formation of an offshore sand sheet and the southerly progradation of the Cap Ferret spit. Given current predictions for SLR and perhaps more importantly, an associated increase in storminess [92], coastal erosion is likely to continue or even increase in the future. The management and stabilisation of dunes by the French Forestry Service will probably prevent large-scale inland migration [21], although the littoral dunes will remain unstable. On such a mobile coast attempts to artificially maintain and fix the land-sea boundary using hard defences are likely to be unsuccessful.

\section{Acknowledgements}

This work was supported by the CNRS programme 'Morphogenèse, paysages et peuplements holocènes en Aquitaine' and by the EC funded Human Capital and Mobility Network (CHRX-CT94-0541), Coastal Environments. The authors wish to thank Dr. S. Mellalieu for his valuable help in a thorough review of the preliminary manuscript and the anonymous reviewers for their constructive criticisms and suggestions. This paper is Bordeaux University, DGO-UMR CNRS 5805 contribution no. 1236.

\section{REFERENCES}

[1] Allard A., Dubreuilh J., Marionnaud J.M., Contribution de la méthode historique à la résolution d'un problème de géologie récente: excmple du Bas-Médoe (Gironde), Bull. BRGM $\left(2^{\text {eme }}\right.$ série), Section I, (1) (1974) 1-14.
[2] Allen G.P., Étude des processus sédimentaires dans l'estuaire de la Gironde, thèse de Doctorat d'Etat $n^{\circ} 369$, Université Bordcaux 1, 1972,314 p. 
[3] Allen G.P., Castaing P., Suspended sediment transport from the Gironde estuary (France) onto the adjacent continental shelf, Mar. Geol. 14 (1973) 47-53.

[4] Allen G.P., Castaing P., Carte de répartition des sédiments superficiels sur le plateau continental du golfe de Gascogne, Bulletin de l'Institut de Géologie du Bassin d'Aquitaine, Bordeaux, 21 (1977) 255-261.

[5] Allen G.P., Posamentier H.W., Sequence stratigraphy and facies model of an incised valley fill: the Gironde Estuary, France, J. Sediment. Petrol. 63 (3) (1993) 378-391.

[6] Allen J.R.L., Salt-marsh growth and stratification: a numerical model with special reference to the Severn Estuary, southwest Britain, Mar. Geol. 95 (1990) 77-96.

[7] Allen J.R.L., Late Flandrian shoreline oscillations in the Severn estuary: change and reclamations at Arlingham, Gloucestershire. Phil. T. Roy. Soc. London, A 330 (1990) 315-334.

[8] Allen I.R.I., The Severn Fstuary in southwest Rritain: its retreat under marine transgression, and fine-sediment regime, Sediment. Geol. 66 (1990) 13-28.

[9] Arbouille D., La sédimentation de la plate-forme continentale Nord-Aquitaine au Quaternaire terminal: un exemple de système transgressil, thèse de $3^{\text {ème }}$ cycle $\mathrm{n}^{\circ} .207$, Université Bordeaux 1, 1987, $196 \mathrm{p}$.

[10] Arbouille D., Legigan P., Weber O., Séquences élémentaires types du proche plateau interne nord-aquitain, Bulletin de l'Institut de Géologie du Bassin d'Aquitaine, Bordeaux, 38 (1985) 31-48.

[11] Barrere P., Dynamics and management of the coastal dunes of the Landes, Gascony, France, in: Sheehy-Skeffington C. (Ed.), Coastal Dunes, Rotterdam, 1992, pp. 25-32.

[12] Beets D.J., Van Der Valk L., Stive M.J.F., Holocene evolution of the coast of Holland, Mar. Geol. 103 (1992) 423-443.

[13] Bernabo J.C., Quantitative estimates of temperature changes over the last 2700 years in Michigan based on pollen data, Quaternary Res. 15 (1981) 143-159.

[14] Bressolier C., Froidefond J.M., Thomas Y.-F., Chronology of coastal dunes in the South-West of France, Catena (Suppl. 18) (1990) 101-107.

[15] Carter R.W.G., Wilson P., Aeolian processes and deposits in northwest Ireland, in: Pye K. (Ed)., The Dynamics and Environmental Context of Acolian Sedimentary Systems, special publication no. 72, The Geological Society, London, 1993, pp. 173-190.

[16] Castaing P., Le transfert à l'Océan des suspensions estuariennes. Cas de la Gironde, thèse de Doctorat d'Etat $n^{\circ} 701$, Université de Bordeaux 1, 1981, $530 \mathrm{p}$.

[17] Castaing P., Co-oscillating tide controls long-term sedimentation in the Girondle estuary, France, Mar. Geol. 89 (1989) 1-9.

[18] Castaing P., Allen G.P., Mechanisms controlling seaward escape of suspended sediment from the Gironde: a macrotidal estuary in France, Mar. Geol. 40 (1981) 101-118.

[19] Castaing P., Jouarneau J.M., Les apports sédimentaires actuels d'origine continentale aux océans. Bulletin de l'Institut de Géologie du Bassin d'Aquitaine, Bordeaux, (41) (1987) 53-65.
[20] Castaing P., Froidefond J.M., Weber O., Contrôle saisonnier des apports en suspension dans le golfe de Gascogne par la structure hydrologique des eaux du Plateau, in: $4^{\text {ène }}$ Congrès Français de Sédimentologie, Lille, France, Résumés - n ${ }^{\circ} 19$, Association des Sédimentologistes Français, 1993, pp. 77-78.

[21] Christiansen C., Dalsgaard K., Moller J.T., Bowman D., Coastal dunes in Denmark. Chronology in relation to sea level, Catena (Suppl. 18) (1990) 61-70.

[22] Dansgaad W., Johnsen S.J., Reeh N., Gundestrup N., Clausen H.B., Hammer C.U., Climate changes, Norsemen and modern man, Nature 255 (1975) 24-28.

[23] Diot M.F., Tastet J.P., Palaeo-environements Holocenes et limites chronoclimatiques enregistrếs dans un marais estuarien de la Gironde (France), Quaternaire 6 (2) (1995) 85-94.

[24] Douglas B.C., Global sea level rise, J. Geophys. Res. 96 (C1) (1991) 6981-6992.

[25] Dubrenith J., Marionnaud .J.M., Carte géol. France (1/50 000), Feuille Lesparre-Médoc-Le Junca (753-754), Orléans: BRGM Notice explicative par Dubreuilh J., Marionnaud J.M., Andreieff P., 1973, 47 p.

[26] Dubreuilh J., Carte géol. France (1/50 000), Feuille Archachon (825), Orléans: BRGM Notice explicative par Dubreuilh J, Karnay G., Bouchet J.M., Le Nidre Y., 1992, 53 p.

[27] Enjalbert H., Géomorphologie, in: Atlas d'Aquitaine, Tcchnip, Paris. 4 (1973) I-II.

[28] Fairbanks R.G., A 17,000-year glacio-eustatic sea level record: influence of glacial melting rates on the Younger Dryas event and deep-ocean circulation, Nature 342 (1989) 637-642.

[29] Fairbridge R.W., Eustatic changes in sea level, Phys. Chem. Earth 5 (1961) 99--185.

[30] Froidefond J.M., Processus d'évolution d'un littoral sableux au cours de l'Holocène. Application au domaine aquitain. Présentation d'une méthode de géomorphologie dynamique et quantitative, thèse de Doctorat d'Etat $n^{\circ} 724$, Université Bordeaux 1 , 1982, 273 p.

[31] Froidefond J.M., Legigan P., La Grande Dune du Pilat et la progression des dunes sur le littoral aquitain, Bulletin de l'Institut de Géologie du Bassin d'Aquitaine, Bordeaux 38 (1985) $69-79$.

[32] Froidefond J.M., Castaing P., Mirmand M., Ruch P., Analysis of the turbid plume of the Gironde (France) based on SPOT radiometric data, Remote Sens. Environ. 36 (1991) 149-163.

[33] Froidefond J.M., Prud'homme R., Coastal erosion and aeolian sand transport on the Aquitaine coast, France, Acta Mecanica (Suppl. 2) (1991) 147-159.

[34] Gensous B., Contribution à l'étude des sédiments meubles superficiels du plateau continental aquitain. Relations avec le régime hydraulique actuel, thèse de $3^{\text {ème }}$ cycle $n^{\circ} 939$, Université Bordeaux 1, 1971, 58 p.

[35] Godwin H., Suggate R.P., Willis E.H., Radiocarbon dating of the eustatic rise in ocean-level, New Zeal. Geol. Survey 181 (1958) 1518-1519.

[36] Gould H.R., Morgan J.P., Coastal Louisiana swamps and lowlands, in: Rainwater E.H., Zingula R.P. (Eds.), Geology of 
the Gulf Coast and Central Texas: Houston, Texas, Houston Geological Society, Houston, 1962, pp. 287-341.

[37] Greensmith J.T., Tucker E.V., The origin of holocene shell deposits in chenier plain facies of Essex (Great Britain), Mar. Geol. 7 (1969) 403-425.

[38] Greensmith J.T., Tucker E.V., Major flandrian transgressive cycles, sedimentation and palaeogeography in the coastal zone of Essex, England, Geol. Mijnbouw 55 (3 4) (1976) 131-146.

[39] Grove J.M., The Little Ice Age, Methuen, London and New York, 1988, $98 \mathrm{p}$.

[40] Howa H., L'érosion du littoral du Nord-Médoc (Gironde), Bulletin de l'Institut de Géologie du Bassin d'Aquitaine, Bordeaux, 38 (1985) 57-68.

[41] Jouanneau J.M., Matières en suspension et oligo-éléments métalliques dans le système estuarien girondin: comportement et flux, thèse de Doctorat d'Etat $\mathrm{n}^{\circ} 732$, Université Bordeaux 1, 1982, $150 \mathrm{p}$.

[42] Jouanneau J.M., Latouche C., The Gironde estuary, in: Füchtbauer H., Lisitzyn A.P., Milliman J.D., Seibold E. (Eds.), Contributions to Sedimentology, Stuttgart, 1981, 115 p.

[43] Jouanneau J.M., Granboulan J., Feral A., Villerot M., Étude des paramètres sédimentologiques de la crème de vase dans le système fluvio-estuarien de la Gironde, in : Colloque francojaponais d'Océanographie, France, 1985, pp. 75-90.

[44] Jouanneau J.M., Weber O., Les flux particulaires d'origine estuarienne piégés dans la vasière ouest-Gironde, Anais do Instituto Hidrografico, 10 (1989) 59-63.

[45] Kana T.W., A mesoscale sediment budget for Long Island, New York, Mar. Geol. 126 (1995) 87-1 10.

[46] Karnay G., Carte géol. France (1/50 000), Feuille La Teste (849), Orlédns: B.R.G.M. Notice explicative par Karnay G., Dubreuilh J., Bouchet J.M., 1992, 52 p.

[47] Kidson C., Criteria for the evaluation of "evidence" of higher Holocene sea levels, Oceanis 7 (4) (1981) 381-388.

[48] Kidson C., Sea-level changes in the Holocene, in: van de Plassche O. (Ed.), Sea-level Research: A Manual for the Collection and Evaluation of Data, Geo Books, Norwich, 1986, pp. 27-64.

[49] Klijn J.A., Dune forming factors in a geographical context, Catena (Suppl. 18) (1990) 1-13.

[50] Klijn J.A,. The younger dunes in the Netherlands; chronology and causation, Catena (Suppl. 18) (1990) 89-100.

[51] Klingebiel A., Gayet J., Fluvio-lagoonal sedimentary sequences in Leyre Delta and Arcachon Bay, and Holocene sea level variation, along the Aquitaine coast (France), Quaternary Intern. 29/30 (1995) 111-117.

[52] Klingebiel A., Tastet J.P., Histoire géologique de l'embouchure de l'estuaire de la Gironde. Actes du colloque du Conservatoire de l'estuaire de la Gironde, I es Cahiers n 2, Saint-Genrges de Didonne, 1995, pp. 9-24.

[53] Lamarche V.C., Palaeoclimatic inferences from Long-Tree ring records, Science 183 (4129) (1974) 1043-1048.

[54] Lamb H.H., Climate: Past, Present and Future. II. Climatic History and the Future, Methuen, London, 1977, 835 p.
[55] Larson M., Kraus, Prediction of cross-shore sediment transport at different spatial and temporal scales, Mar. Geol, 126 (1995) $111-127$.

[56] Lee H.J., Chun S.S., Chang J.H., Han S.J., Landward migration of isolated shelly sand ridge (chenier) on the macrotidal flat of Gomso Bay, west coast of Korea: controls of storms and typhoon, J. Sediment. Res. A64 (14) (1994) 886-893.

[57] Legigan P., L'élaboration de la formation du sable des Landes. dépôt résiduel de l'environnement sédimentaire PliocènePléistocène centre Aquitain, thèse de Doctorat d $d^{2}$ Etat $n^{\circ} 642$, Université Bordeaux 1, 1979, 429 p.

[58] Legigan P., Castaing P., La pénétration des sables marins dans les estuaires: cas de la Gironde, C.R. Acad. Sci. 292 (2) (1981) 207-211.

[59] Le Roy, Ladurie E., Histoire du climat depuis l'an mil, Nouvelle bibliothèque scientifique, Flamarion, Paris, 1967, 376 p.

[60] Lesueur P., Tastet J.P., Facies, internal structures and sequences of modern Gironde-derived muds on the Aquitaine inner shelf, France, Mar. Geol. 120 (1994) 267-290.

[61] Lesueur P., Weber O., Marambat L., Tastet J.P., Jouanneau J.M., Turon J.L., Datation d'une vasière de plate-forme atlantique au débouché d'un estuaire: la vasière à l'ouest de la Gironde (France) est d'âge historique (VI ${ }^{\mathrm{e}}$ siècle à nos jours), C.R.. Acad. Sci, 308 (II) (1989) 935-940.

[62] Lesueur P., Tastet J.P., Marambat L., Shelf mud fields formation withing historical times: examples from offshore the Gironde estuary, France, Cont. Shelf Res. 16 (14) (1996) $1849-1870$.

[63] List J.H., Large scale coastal behaviour 93', U.S. Geol. Surv., Open File Rep. 93-381 (1993) 238.

[64] List J.H., Terwindt J.H.J., Large-scale coastal behavior, Mar. Geol. 126 (1995) 1-3.

[65] Marambat J., Paléoenvironnements et empreinte anthropique dans I'Ouest Aquitain et la Saintonge à l'Holocène. L'apport de la palynologie, thèse de Doctorat de l'Université Bordeaux 1 $\mathrm{n}^{\circ} 750,2$ vols., 1992, $226 \mathrm{p}$.

[66] Marionnaud J.M., Carte géol. France (1/50 000), Feuille St-Vivien-de-Médoc-Soulac-sur-Mer (729-730), Orléans: BRGM (Notice explicative par Dubreuilh J., Marionnaud J.M., 1973,45 p), 1972

[67] Migniot C., L'évolution de la Gironde au cours des temps, Bulletin de l'Institut de Géologie du Bassin d'Aquitaine 11 (fasc. 2) (1971) 221-279.

[68] Nagy Breitenstein G., Analyse quantifiée de l'évolution hydromorphologique séculaire de l'estuaire amont de la Gironde, thèse de Doctorat de l'Université Bordeaux 1, $\mathrm{n}^{\circ} 789,1993$, $102 \mathrm{p}$.

[69] Niedoroda A.W., Reed C.W., Swift D.J.P., Arato H., Hoyanagi K., Modeling shore-normal large-scale coastal evolution, Mar. Geol. 126 (1995) 181-199.

[70] Orme A.R., Coastal Dunes, Changing Sea Level, and Sediment Budgets (special issue), J. Coastal Res. 3 (1988) 127-129.

[71] Pethick J.S., Long-term accretion rates on tidal salt marshes, J. Sediment Petrol. 51 (2) (1981) 571-577. 
[72] Pirazzoli P.A., World Atlas of Holocene Sea-level Changes, Elsevier Science Publishers B.V., Amsterdam, 1991, 300 p.

[73] Pirazzoli P.A., Les littoraux leur évolution, Géographie d'aujourd'hui, Nathan, Paris, 1993, $191 \mathrm{p}$.

[74] Pye K., Models of transgressive coastal dune building episodes and their relationship to Quaternary sea level changes: a discussion with reference to evidence from eastern Australia, in: Clark M. (Ed.), Coastal Research, Cambridge 1984, pp. 8199.

[75] Pye K., Introduction: the nature and significance of aeolian sedimentary systems, in: Pye K. (Ed.), The Dynamics and Environmental Context of Aeolian Sedimentary Systems, special publication no. 72, The Geological Society, London, 1993, pp. $1-4$.

[76] Pye K., Late Quaternary development of coastal parabolic megadune complexes in northeastern Australia, Spec. Publs. Int. Assoc. Sediment. 16 (1993) 23-44.

[77] Pye K., Controls on long-term salt matsh accretion and erosion in the wash, eastern England, J. Coastal Res. 11 (2) (1995) 337-356.

[78] Pye K., Bowman G.M., The holocene marine transgression as a forcing function in episodic dune activity on the eastern Australian coast. Coast, Geomorph. in Australia (1984) 179-196.

[79] Pye K., Neal A., Late Holocene dune formation on the Sefton coast, northwest England, in: Pye K. (Ed.), The Dynamics and Environmental Context of Aeolian Sedimentary Systems, special publication no. 72, The Geological Society, London, 1993, pp. 201-217.

[80] Pye K., Stokes S., Neal A., Optical dating of aeolian sediments from the Sefton coast, northwest England in: Proceedings of the Geologists' Association, 106 (1995) 281-292.

[81] Shennan I., Tooley M.J., Davis M.J., Haggart B.A., Analysis and interpretation of Holocene sea-level data, Nature 302 (1983) 404-407.

[82] Shepard F.P., Suess H.E., Rate of postglacial rise of sea level, Science 123 (1956) 1082-1083.

[83] Tastet J.P., Les paysages du littoral Aquitain, témoins de l'évolution des environnements: l'exemple du Nord-Médoc, in : Journée Aquitaine du Littoral, pour une Gestion Concertée de l'Environnement Littoral, Bordeaux, Région Aquitaine, 1994, pp. 9-18.

[84] Tastet J.P., Morphogenèse holocène de la zone littorale aquitaine: l'exemple du Nord-Médoc, Pétrole et techniques 390 (1994) 31-35.

[85] Tastet J.P., Diot M.F., Carbonel P., Changements climatiques et paléoenvironnementaux holocènes enregistrés dans les marais estuariens de la Gironde, in : Colloque 'Quaternaire I' :
Echelles des variations chronoclimatiques quaternaires et Réponse des Environnements, Montpellier. CNF and INQUAAFEQ, U.R.A. CNRS 327 (1994) 48.

[86] Ters M., Les variations du niveau marin depuis 10000 ans, le long du littoral atlantique français, in : Le Quaternaire, géodynamique, stratigraphie et environnement. Bulletin Association Française de l'étude du Quaternaire, (Suppl. 36) $\left(9^{\mathrm{e}}\right.$ Congrès International de l'INQUA) (1973) 114.135.

[87] Todd T.W., Dynamic division: influence of longshore currenttidal flow interaction on chenier and barrier island plains, J. Sediment. Petrol. 38 (1968) 734-746.

[88] Turcq B., Faciès et formes sédimentaires du plateau continental Nord aquitain. Réponse aux processus hydrodynamiques actuels, thèse de $3^{\text {ème }}$ cycle $n^{\circ}$. 1967, Université de Bordeaux $1,1984,192 \mathrm{p}$.

[89] Verger F., Marais et wadden du littoral français, Biscaye Frères, Bordeaux, 1968, $541 \mathrm{p}$.

[90] Vigneaux M., Caralp M., Klingebiel A., Latouche C., Moyes J., Sur l'origine des sédiments fins superficiels du plateau continental atlantique au large de la Gironde (France), in: The 2nd Intcrnational Ocean Development Conference, Tokyo, Japan, 1 (1972) 372-394.

[91] Wanless II.R., Sea level is rising - so what? J. Sediment. Petrol. 52 (1982) 1051-1054.

[92] Warrick R.A., Oerlemans J., Sea level rise, in: Houghton, J.T., Jenkins, G.J., Ephraums, J.J. (Eds.), Climatic Change: The IPCC Scientific Assessment, Cambridge University Press, Cambridge, 1990.

[93] Weber O., Arbouille D, Faugères J.C., Séquences sédimentaires grano-classées de haute énergie sur une plate-forme continentale à niveau marin constant: exemple de la plate-forme atlantique du Nord de l'Aquitaine (France), C.R. Acad. Sci. 304 (2) (1987) 1191-1194.

[94] Weber O., Jouanneau J.M., Ruch P., Mirmand M., Grain-size relationship between suspended matter originating in the Gironde estuary and shelf mud-patch deposits, Mar. Geol. 96 (1991) 159-165.

[95] Wijnberg K.M., Morphologic behaviour of a barred coast over a period of decades, Faculteit Ruimtelijke Wetenschappen Universiteit Utrecht, Utrecht, 1995, 245 p.

[96] Williams L.D., Wigley T.M.L., A comparison of evidence for Late Holocene summer temperature variations in the northern Hemisphere, Quaternary Res. 20 (1983) 286-307.

[97] Zagwijn W.H., The formation of the younger dunes on the west coast of the Netherlands (AD 1.000-1600), Geol. Survey of the Netherlands 63 (1984) 259-268. 